\title{
REUSE OF WASTEWATER FROM POLYESTER FIBRES DYEING PROCESS BY THERMAL FIXATION WITH DYE ACID BASE: CASE STUDY IN A BRAZILIAN AUTO PARTS FACILITY
}

\begin{abstract}
W. Q. Lamas ${ }^{\mathrm{a}}$
and R. S. Fujisawa ${ }^{b}$

${ }^{\mathrm{a}}$ Universidade Estadual Paulista

Faculdade de Engenharia

Departamento de Energia

Av. Dr. Ariberto Pereira da Cunha, 333

12516-410, Guaratinguetá, São Paulo, Brasil

wendell@feg.unesp.br

${ }^{\mathrm{b}}$ Autoliv do Brasil Ltda.

Rua Marginal F. R. Pinheiro, 551

12043-000, Taubaté, São Paulo, Brasil

ronfu@bol.com.br

ABSTRACT

This work aims to test biodegradable chemicals into treatment of textile waste water from an auto parts facility with goal of reuse of water treated in dyeing process of lace used in safety belts. It presents a method that suits the treatment of waste water with local environmental regulations and allows the reuse of water through the adoption of actions that replace the conventional physical-chemical treatment by biodegradable products, which naturally extend the possibility of reuse beyond the process and increase the quality of water for reuse in that one, allowing satisfy the requirements of product quality demanded by the market. This work proposes substitution of some chemicals by biodegradable products and comparison to previous results obtained with current treatment for the same conditions preestablished. Also the ultra-filtration method had evaluated and its results were compared to traditional process and to new proposal. According to results obtained, replacement of traditional chemicals by biodegradable products is technical and economical viable and attends to the waste water reuse policy proposed.
\end{abstract}

Keywords: biodegradable chemicals; energy and economic efficiency; textile waste water; waste water reuse; water consumption.

\section{INTRODUCTION}

Dyeing process generates several heterogeneous and complex waste water. These characteristics and some laws impositions that require treatments more efficient had encouraged development of new technologies and products that have searched for better and more appropriate treatment of those waste water, always considering costs, time, and efficiency of existing processes on reuse of waste water treated.

The best use of raw materials, water, energy, reduction into generation of waste etc., provide financial gains, which can be obtained with application of lean manufacturing. This technique provides competitiveness through reduction of yield costs, improvement in workplace, and improvement of business image towards the community and its employees.

The Brazilian Ministry of the Environment, through the National Council for the Environment (CONAMA), established environmental laws and standards very restrictive, such as MMA (2005) that classifies water bodies and provides environmental directives for this classification. Also CETESB (1976) had established environmental policies according to the National Policy of Water Resources (ANA, 1997). The World Health Organization also had related guidelines for reuse and drinking water quality based on scientific research and epidemiological finding to provide protection of public health and the preservation of the environment (Hespanhol, 1994).

These normative associated to determine competitiveness of markets for companies to be more competent, in point of view of environment and production, any increase of industrial yield demand is directly related to lower cost of inputs and less pollutants generation.

The need to reduce waste and minimize water consumption in the industry is forcing the industry to change habits and processes related to water consumption, thus opening the way for the use of waste water and less quality water on their facilities.

The World Health Organization defined that is the water reuse and its variants: the direct reuse is planned and deliberate use of treated waste water for certain purposes such as irrigation, industrial use, aquifer recharge, and drinking water; the indirect reuse occurs when the water is used, one or more times for domestic or industrial purposes, and it is discharged into surface water or groundwater and reused downstream, in diluted form; recycling is the reuse of water internally to industrial plants, aiming to water saving and pollution control (WHO, 1973).

Also water reuse is classified in two main categories: drinking and not-drinking. The drinking reuse can be direct or indirect, where last one is divided in aquifer recharge and increase of surface 
sources, and not-drinking reuse is divided in urban reuse, agricultural reuse, recreational reuse, environmental reuse, industrial reuse, aquifer recharge and aquaculture (Westerhoff, 1984; USEPA, 2004).

There are many technologies available to achieve a better quality in parameters for water reuse, being physical, chemical, and possibly biological.

Treatments such as adsorption onto activated carbon, oxidation with ozone, chlorine dioxide, and hydrogen peroxide, separation by membrane (microfiltration, ultra-filtration, nano-filtration, and reverse osmosis), reverse electrolysis, ion exchange, distillation, and chemical precipitation are the stateof-art referred to treatment of waste water for reuse (Hosetti and Frost, 1995; Vandevivere et al., 1998; Kalliala and Talvenmaa, 2000; Gregory, 2003; ElNaggar et al., 2005; Oenning-Junior and Pawlowsky, 2007).

Several studies based on dyeing effluent recycling or removing had been developed, such as ultra-filtration membranes using indigenously available polymer (Joshi et al., 2001), nano-filtration membrane by UV-photographing (Akbari et al., 2002), advanced oxidation processes and chemical treatment methods (Azbar et al., 2004), separation of acidic dyestuffs from aqueous solution by nanofiltration ( $\mathrm{Ku}$ et al., 2005), spiral-wound nanofiltration (Ji et al., 2006), alkali reduction waste water (Fan et al., 2007), nano-filtration membrane to reduce the quantity of the disposed water (Avlonitis et al., 2008), nano-filtration in secondary stage after a pretreatment with ultra-filtration (Gozalvez-Zafrilla et al., 2008), and others.

The effect of the effluent disposal is pollution and it is recognized as a process in which, somehow, properties of air or water are changed. The simple introduction of hot or coloured water in a water flow is an act of pollution.

The dyeing process of laces generates emissions of pollutants in solid, liquid, and gaseous states. The emissions of liquid pollutants cause further contamination and alteration of environment and depend on type of fibres processed and chemicals used. Other factors that determine quantity and quality of waste water are operations performed and technology used in its implementation.

This work aims to test biodegradable chemicals into treatment of textile waste water from an auto parts facility with goal of reuse of water treated in dyeing process of lace used in safety belts.

This paper presents a method that suits the treatment of waste water with local environmental regulations and allows the reuse of water through the adoption of actions that replace the conventional physical-chemical treatment by biodegradable products, which naturally extend the possibility of reuse beyond the process and increase the quality of water for reuse in that one, allowing satisfy the requirements of product quality demanded by the market.

\section{MATERIAL AND METHODS}

The chemical treatment is used in this facility for now, which essentially consists in converting the pollutants into a solid phase, called sludge, detachable from water purified by a process of sedimentation and filtration. The facility is quite compact and treatment process produces little sludge.

Treatment sequence of this waste water follows these procedures:

- transference of effluents for treatment tank in proportions of 9/1 (waste diluted/waste concentrated);

- normalization of waste water with $\mathrm{H}_{2} \mathrm{SO}_{4}$ and $\mathrm{pH}$ stabilization in range of 8-10;

- addition of organic polymer for colour removal;

- addition of polyvinyl of aluminium until the $\mathrm{pH}$ range of 6-7;

- addition of polyelectrolytes $0.20 \%$ to flocculate, maintaining the stirring until it has a precipitation of flakes;

- suspension of agitation and allowing the treated effluent to rest for a minimum of 90 minutes. After that, the supernatant water is filtered and the precipitate (sludge) is transferred to sludge receiving tank sequentially transferred to sludge thickeners;

- flakes formed after addition of polyelectrolytes are broken with transferring. It is added a ratio of polyelectrolytes in sludge thickening process to have flakes increasing. Each thickener tank has four valves numbered so it can filter by parties and has a settling of about 90 minutes;

- water clarified with small supernatant particles is filtered by activated carbon filter, where it will be forwarded to the launch in rainwater (river).

Figure 1 shows process diagram related to the current chemical process. 


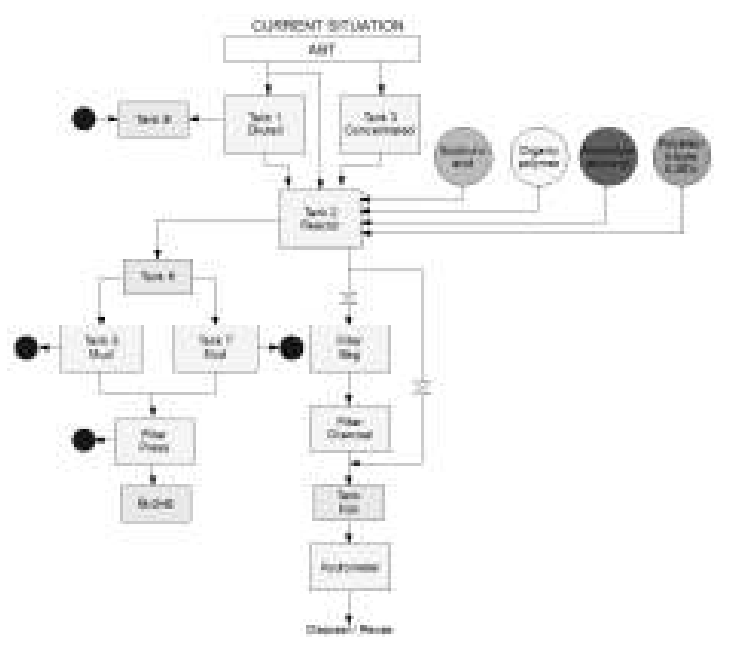

Figure 1. Process diagram for current chemical treatment.

This work proposes substitution of some chemicals by biodegradable products and comparison to previous results obtained with current treatment for the same conditions pre-established. Also the ultrafiltration method had evaluated and its results were compared to traditional process and to new proposal.

\section{RESULTS AND DISCUSSION}

In this section, biodegradable products are applied to the current chemical treatment procedures and these results are compared to previous results with traditional chemicals.

\section{Chemical Treatment Process Using Biodegradable Products}

The current treatment process is not efficiency to remove colour from waste water (important feature for reuse in dyeing) and it is impossible to reuse this treated water because of it. New products with characteristic of biodegradability have investigated in order to solve this problem, also colour removal efficiency and low cost are desirable characteristics. A crucial condition is that met the National and the State legislation, regarding effluent launch into the rivers (CETESB, 1976; ANA, 1997; MMA, 2005).

The new provider was defined after undertaking several bench tests (Jar-Test) with new products and made analysis of treated waste water. The chemical treatment had increased the following new products: coagulant - flocculant and decolourant; decolourant; amphoteric polymer; and, anti-odour. Figure 2 shows chemical process with inclusion of biodegradable products in it.

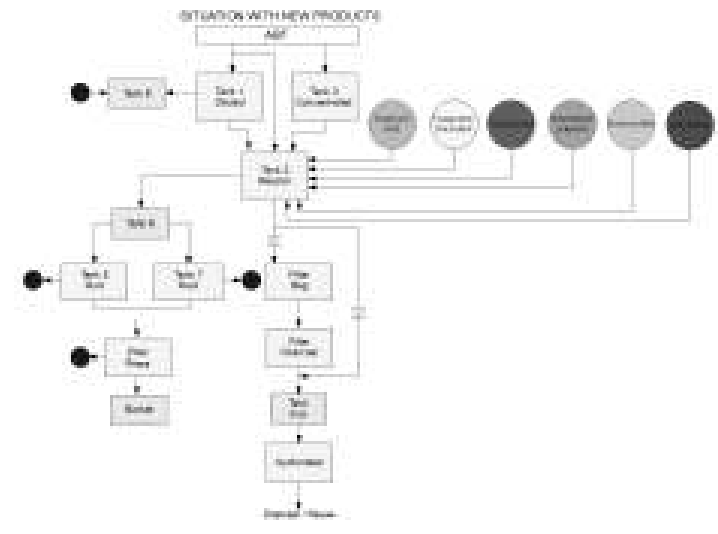

Figure 2. Process diagram for treatment proposed with the new products.

Following the main characteristics of each one of the new products.

\section{Coagulant - flocculant and decolourant}

- Product is compatible with the treatment processes both physical-chemical and biological;

- Better performance in the $\mathrm{pH}$ range between 6.5 and 7.0 ;

- Product has high yield in waters with heavy load of contaminants having a rapid rate of coagulation, less acidic than other coagulants, thus providing a considerable reduction in the formation of sludge;

- Great sequestering and dispersing effect, both in acidic and alkaline liquids, not generating nitrogen in the waste water, so it can quickly reach the BOD and COD required;

- Allows total reuse of water for dyeing, tanning, and stamping.

\section{Decolourant}

- Organic biodegradable technology formaldehyde free, used in the removal of water colours of industrial waste water, particularly from industries using dyes, both natural and synthetic (textile, pulp and paper etc.);

- The product acts destabilizing colloids present in the waste water with the formation of flocks;

- Compatible with the treatment processes both physical-chemical and biological;

- Product has the best performance in the $\mathrm{pH}$ range between 6.4 and 6.7 . 


\section{Amphoteric polymer}

- It is an amphoteric polymer of high molecular weight, used in the separation of liquid-solid in the decanting and flotation systems in steel mill, sugar and alcohol plants, textile industries, tannery, pulp and paper, mining etc;

- Biodegradable product.

\section{Anti-odour}

- Composition of special products, with antiodours features;

- It is characterized by its ability to prevent the formation of odours from the decomposition of organic material, usually found in biological waste water treatment, both anaerobic and aerobic;

- Eliminates odours quickly, and its lasting efficiency throughout the process.

The waste water treatment with new products have the following stages:

- Setting the waste water $\mathrm{pH}$ with sulphuric acid in the range from 8 to 10 (Figure 3);

- Adding the coagulant - flocculant and decolourant to the $\mathrm{pH}$ range from 6.5 to 7.0 (Figure 4);

- Adding decolourant that performs best with a $\mathrm{pH}$ range from 6.4 to 6.7 (Figure 4);

- Adding the amphoteric polymer to occur the separation of liquid-solid (Figure 5);

- Using hydrosulfite to assist in colour removal and, in sequence, to apply the antiodour to inhibit odour (Figure 6).

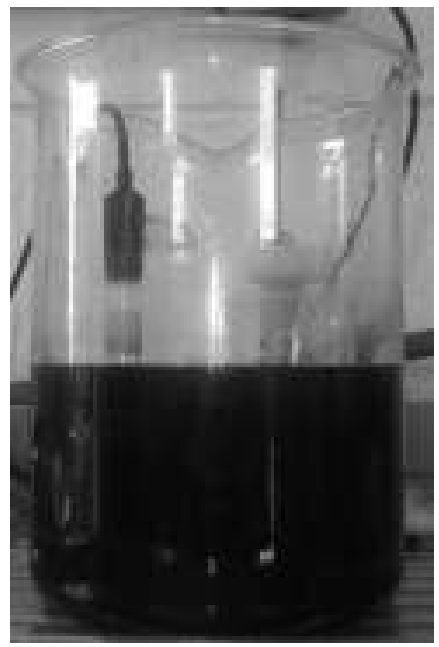

Figure $3 . \mathrm{H}_{2} \mathrm{SO}_{4}$ added to waste water from dyeing process (stage 1).

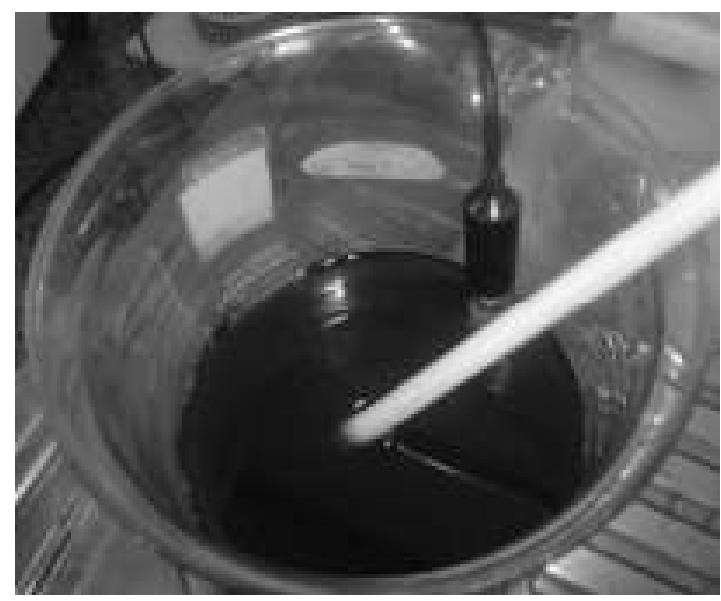

Figure 4. Coagulant - flocculant and decolourant added to the effluent (stages 2 and 3 ).

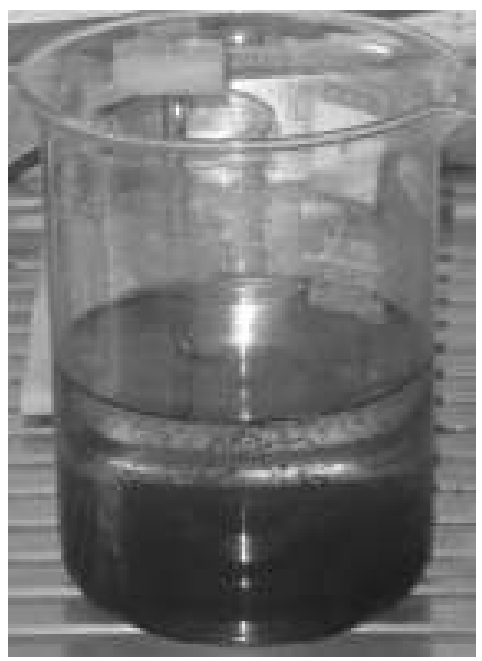

Figure 5. Amphoteric polymer added to the effluent (stage 4).

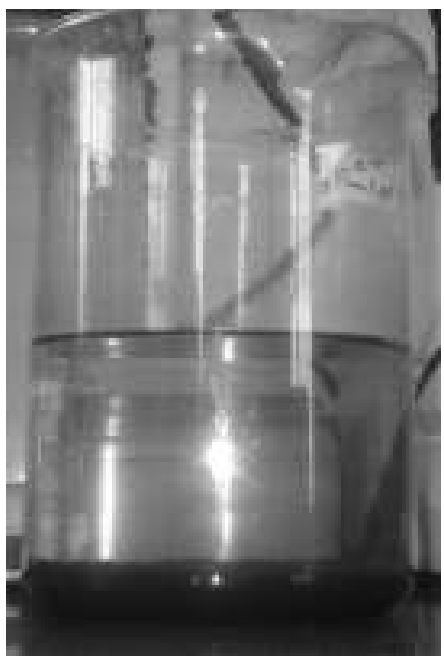

Figure 6. Sodium hydrosulfite and anti-odour added (stage 5). 


\section{Analysis of Results with the Change of Chemicals}

\section{Cost of chemicals}

The chemicals currently used were effective in the waste water treatment in accordance with the National and the State laws of effluent launch into the rivers (CETESB, 1976; ANA, 1997; MMA, 2005), but never appeared as the most suitable products for the purpose of the treated waste water reuse in dyeing process, as well as the cost that was very high (Barclay and Buckley, 2000a; Barclay and Buckley, 2000b).

Table 1 shows monthly values for specific products consumption and their costs for current chemical treatment.

Table 1. Monthly cost of current treatment.

\begin{tabular}{|l|l|l|}
\hline $\begin{array}{l}\text { PRODUCTS USED } \\
\text { IN CURRENT } \\
\text { TREATMENT }\end{array}$ & $\begin{array}{l}\text { Monthly } \\
\text { consumption } \\
\left(\mathbf{m}^{\mathbf{3}}\right)\end{array}$ & $\begin{array}{l}\text { Monthly } \\
\text { value (US\$) }\end{array}$ \\
\hline Aluminium polyvinyl & 3,900 & $4,591.66$ \\
\hline Organic polimer & 900 & $2,661.96$ \\
\hline Polyelectrolyte $\mathbf{0 . 2 0} \%$ & 600 & $4,307.37$ \\
\hline Sulphuric acid & 9,600 & $6,340.45$ \\
\hline Total & 15,000 & $17,901.45$ \\
\hline
\end{tabular}

Table 2 shows monthly values for specific products consumption and their costs for treatment with biodegradable products.

Table 2. Monthly cost of treatment with the biodegradable products.

\begin{tabular}{|l|l|l|}
\hline $\begin{array}{l}\text { NEW PRODUCTS } \\
\text { (BIODEGRADABLE) }\end{array}$ & $\begin{array}{l}\text { Monthly } \\
\text { onsumption } \\
\mathbf{n}^{\mathbf{3}} \text { ) }\end{array}$ & $\begin{array}{l}\text { Monthly } \\
\text { alue } \\
\text { US\$) }\end{array}$ \\
\hline $\begin{array}{l}\text { Coagulant } \text { - flocculant and } \\
\text { bleaching }\end{array}$ & 5,200 & $3,882.40$ \\
\hline Decolorant & 600 & $1,647.15$ \\
\hline Anti-odour & 300 & $2,377.70$ \\
\hline Amphoteric polymer & 25 & 287.16 \\
\hline Sulphuric acid & 8,400 & $5,547.90$ \\
\hline Total & 14,525 & $13,742.31$ \\
\hline
\end{tabular}

Table 3 shows the comparison of monthly cost of current treatment and treatment with biodegradable products.

Table 3. Comparison of monthly cost of current treatment and treatment with biodegradable products.

\begin{tabular}{|l|l|}
\hline Monthly savings with new products $3 \%$ \\
\hline & $3 \%$ \\
\hline
\end{tabular}

Adoption of biodegradable products and simple changes in waste water treatment procedure make possible savings around 3\% per month, around 30\% in a year. Beyond that are savings regarding water consumption because new policy of waste water reuse.

\section{Water consumption}

In the manufacturing plant of laces for use in safety belts is consumed, on average, $1,229 \mathrm{~m}^{3}$ of water per month (Peters and Timmerhaus, 1991). With planning of reuse of treated waste water in dyeing processes (cleaning machinery at each change of status from black lace to colourful lace, preparation of reductive bath, recirculating water in tanks for washing, preparation of polymers in waste water treatment plant, and cleaning the floors in general) with the installation of a tank of $20 \mathrm{~m}^{3}$ for treated water harvesting have been done a reduction of monthly water consumption of $59 \%$ on average as shown in Table 4.

Table 4. Water usage and proposal to reduce water consumption.

\begin{tabular}{|l|l|l|}
\hline Year base: 2008 & $\begin{array}{l}\text { Water } \\
\text { consumption } \\
\left(\mathbf{m}^{\mathbf{3}}\right)\end{array}$ & $\begin{array}{l}\text { Monthly } \\
\text { value } \\
\text { (US\$) }\end{array}$ \\
\hline January & 1,519 & $5,172.62$ \\
\hline February & 999 & $3,411.43$ \\
\hline March & 1,091 & $3,734.19$ \\
\hline April & 1,708 & $5,845.41$ \\
\hline May & 968 & $3,299.01$ \\
\hline June & 1,215 & $4,134.42$ \\
\hline July & 595 & $2,063.63$ \\
\hline August & 1,351 & $4,615.51$ \\
\hline September & 987 & $3,349.80$ \\
\hline October & 1,158 & $4,049.46$ \\
\hline November & 1,596 & $5,655.16$ \\
\hline December & 1,561 & $5,536.20$ \\
\hline Monthly ratio & 1,229 & $4,238.90$ \\
\hline Annual & 14,748 & $50,866.83$ \\
\hline Proposal for monthly & 729 & $2,514.37$ \\
\hline reduction & 11,148 & $38,768.09$ \\
\hline $\begin{array}{l}\text { Proposal for annual } \\
\text { reduction }\end{array}$ & & \\
\hline
\end{tabular}

Table 5 shows results obtained with some specific tests made and visual inspection of these samples. 
Table 5. Comparison between 10 samples in 5 different tests.

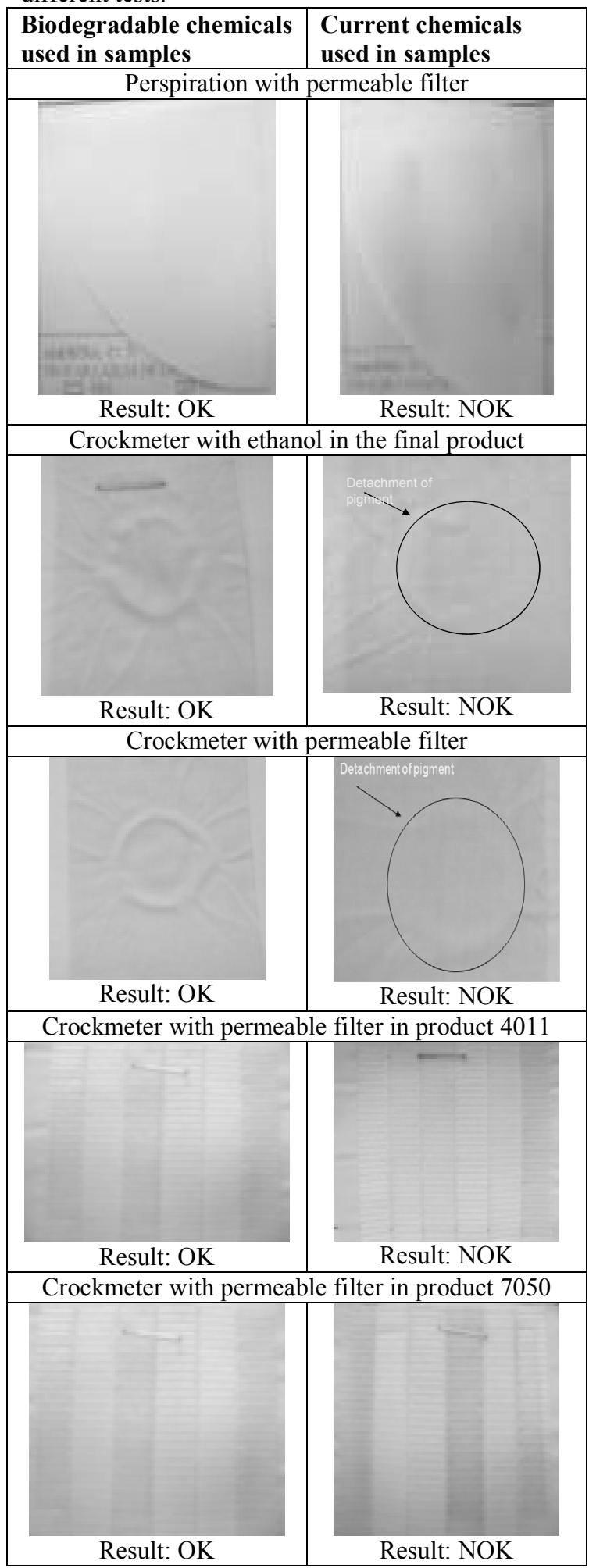

It is possible to see in samples from Table 5 that biodegradable products associated to minor changes in chemical process provide quality of waste water treatment, such that one is reused because the efficiency on colour removal.

\section{Treatment Process Using Ultra-filtration Equipment}

Ultra-filtration is a variety of membrane filtration in which hydrostatic pressure forces a liquid against a semi-permeable membrane. Suspended solids and solutes of high molecular weight are retained, while water and low molecular weight solutes pass through the membrane. This separation process is used in industry and research for purifying and concentrating macromolecular $\left(10^{3}-10^{6} \mathrm{Da}\right)$ solutions, especially protein solutions (Lutz and Raghunath, 2007; Hank and Wyckoff, 2010). Figure 7 shows the flow chart of a typical ultra-filtration process.

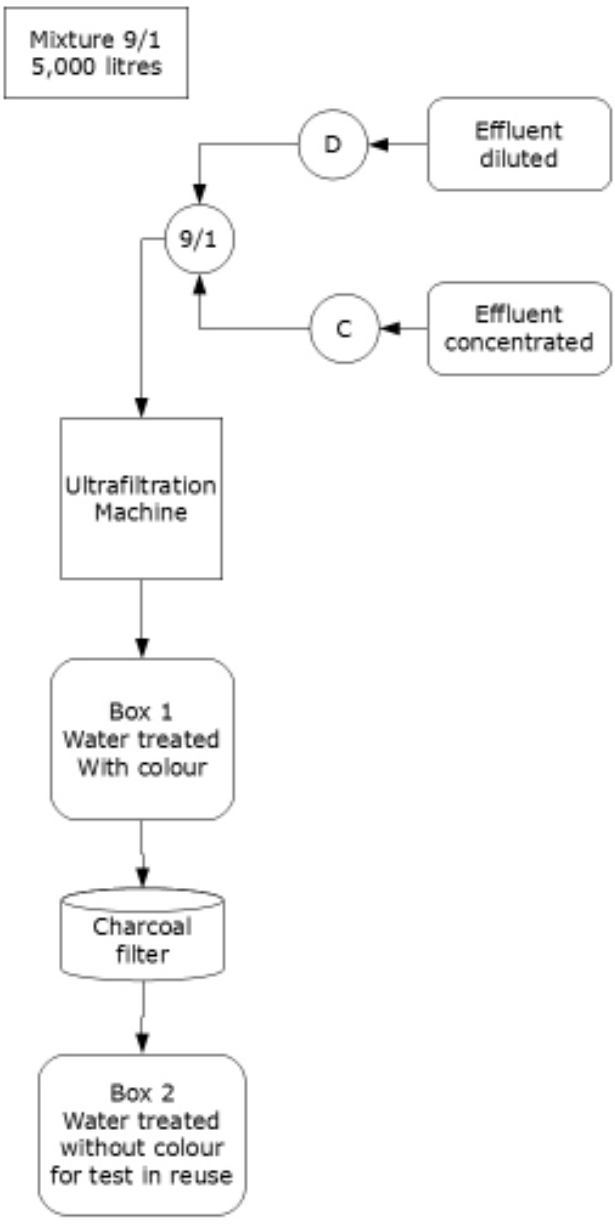

Figure 7. Flow chart of ultra-filtration process.

This ultra-filtration process application had performed in two main stages, such as described below.

In stage 1 , the test had consisted of performing a mixture $9 / 1 \quad-$ diluted and concentrated, approximately 2,500 litres. Catch $\mathrm{pH}$ to the range 
from 7 to 8 with sulphuric acid and the mixture is sent to ultra-filtration machine, as showed in Figure 7.

After passing through membranes of thee machine, water kept the COLOUR and lost all solids. This water was analysed by the laboratory AMPRO and met the standards established by current legislation, with the exception of colour (including with missing of item AMMONIA - analysis report \#0409026 from laboratory AMPRO - maximum value allowed: $5.0 \mathrm{mg} / 1$; value found: $<0.001$ ).

In this test, were treated $2.5 \mathrm{~m}^{3}$ of water, which returned to tanks and were treated in the physicalchemical process. Was noted in the data sheet for control of flow and membrane saturation: start: 59 seconds for 1 litre; in 24 hours: 2'39' for 1 litre.

In stage 2, for colour removal: after repeat all steps of the first stage, the coloured water passes through a charcoal filter with particle size of "8/25 mesh", according to indication of the local sanitation company.

It carried out the bench test with charcoal and colour was removed. A $1.5 \mathrm{~m}^{3}$ sample was treated and allows the maintenance personnel perform the installation of water tank \#2 in the containment area so that the tests are carried out with charcoal and reuse the water in the production process.

The water was passed through a charcoal filter and had resulted in the staining shown in Figure 8.

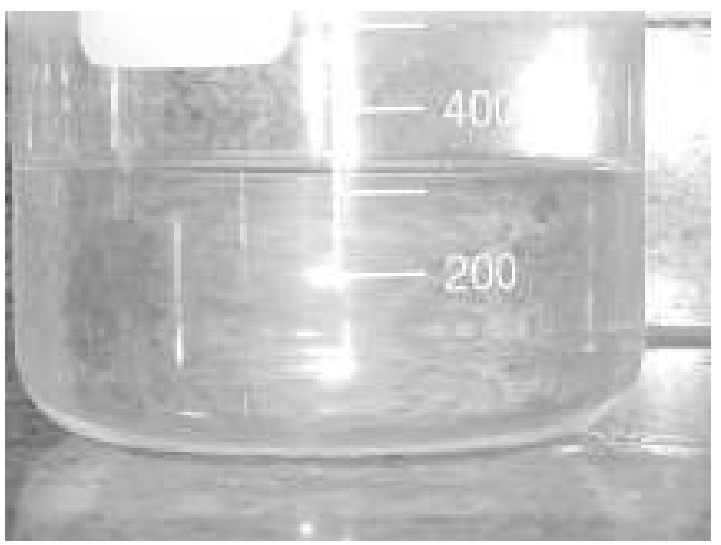

Figure 8. Water after completion of stage 2.

This water was stored in "cylinders" and reused in washing boxes in dyeing process.

This test was approved, according to the quality report presented by the contracted laboratory.

Based on these two bench tests, it can perform the analysis of the results of ultra-filtration system.

The ultra-filtration system had showed efficiency on the results of treated water, but the cost of its implementation is highest than chemical process. Also, it would require a drastic change in the existing lay-out that due to this factor should be reanalysed when there is a need to adapt the new plant.

\section{CONCLUSIONS}

Based on the results obtained in the technical and economic analysis it is concluded that the implementation of new technologies or products used to treat the dyeing process waste water aimed at better utilization and minimize the use of natural resources, will considerably reduce the water consumption and therefore its cost. In this new proposal the cost of water was reduced monthly in about $59 \%$ and the cost for waste water treatment in about $30 \%$, with a return on this investment in nearly five months (payback).

\section{ACKNOWLEDGEMENTS}

The authors thank companies Autoliv do Brasil Ltda. and Laboratorios Gesco for conducting the test, to Ms. Marilia Mesquita Valverde in coordinating and Mr. Rodrigo Lopes Ferreira for assistance with practical tests and measurements of colorimetry.

\section{REFERENCES}

Akbari, A., Desclaux, S., Remigy, J. C., and Aptel, P., 2002, Treatment of Textile Dye Effluents Using a New Nanofiltration Membrane, Desalination, Vol. 149, No. 1-3, pp. 101-107.

Avlonitis, S. A., Poulios, I., Sotiriou, D., Pappas, M., and Moutesidis, K., 2008, Simulated Cotton Dye Effluents Treatment and Reuse by Nanofiltration, Desalination, Vol. 221, No. 1-3, pp. 259-267.

Azbar, N., Yonar, T., and Kestioglu, K., 2004, Comparison of Various Advanced Oxidation Processes and Chemical Treatment Methods for COD and Color Removal from a Polyester and Acetate Fiber Dyeing Effluent, Chemosphere, Vol. 55, No. 1, pp. 35-43.

Barclay, S. and Buckley, C., 2000, Waste Minimisation Guide for the Textile Industry: a Step Towards Cleaner Production, Volume I, University of Natal at Durban / The Pollution Research Group.

Barclay, S. and Buckley, C., 2000, Waste Minimisation Guide for the Textile Industry: a Step Towards Cleaner Production, Volume II, University of Natal at Durban / The Pollution Research Group.

El-Naggar, A. W. M., Zohdy, M. H., Said, H. M., El-Dina, M. S., and Noval, D. M., 2005, Pigment Colors Printing on Cotton Fabrics by Surface Coating Induced by Electron Beam and Thermal Curing, Applied Surface Science, Vol. 241, No. 3-4, pp. 420430.

Fan, L., Zhang, L., Shen, J., Wang, S., and Chen, H., 2007, Study on Recovery and Refining of TA from Alkali Reduction Wastewater, Desalination, Vol. 206, No. 1-3, pp. 353-357.

Gozalvez-Zafrilla, J. M., Sanz-Escribano, D. Lora-Garcia, J., and Leon-Hidalgo, M. C., 2008, Nanofiltration of Secondary Effluent for Wastewater 
Reuse in the Textile Industry, Desalination, Vol. 222, No. 1-3, pp. 272-279.

Gregory, P., 2003, Metal Complexes as Speciality Dyes and Pigments, in: Comprehensive Coordination Chemistry II, Vol. 9, Amsterdam, NL, Elsevier, pp. 549-579.

Hank, M. and Wyckoff, D., 2010, Ultrafiltration in Decentralized Water Treatment Applications, Water Conditioning and Purification Magazine, Vol. 52, No. 4, pp. 22-25.

Hespanhol, I. and Prost, A. M. E., 1994, WHO

Guidelines and National Standards for Reuse and Water Quality, Water Resources, Vol. 28, No. 1, pp. 119-124.

Hosetti, B. B. and Frost, S., 1995, A Review of the Sustainable Value of Effluents and Sludges from Wastewater Stabilization Ponds, Ecological Engineering, Vol. 5, No. 4, pp. 421-431.

Ji, Z., He, Y., and Zhang, G., 2006, Treatment of Wastewater During the Production of Reactive Dyestuff Using a Spiral Nanofiltration Membrane System, Desalination, Vol. 201, No. 1-3, pp. 255266.

Joshi, M., Mukherjee, A. K., and Thakur, B. D., 2001, Development of a New Styrene Copolymer Membrane for Recycling of Polyester Fibre Dyeing Effluent, Journal of Membrane Science, Vol. 189, No. 1, pp. 23-40.

Kalliala, E. and Talvenmaa, P., 2000, Environmental Profile of Textile Wet Processing in Finland, Journal of Cleaner Production, Vol. 8, No. 2, pp. 143-154.

Ku, Y., Lee, P.-L., and Wang, W.-Y., 2005, Removal of Acidic Dyestuffs in Aqueous Solution by Nanofiltration, Journal of Membrane Science, Vol. 250, No. 1-2, pp. 159-165.

Lutz, H. and Raghunath, B., 2007, Ultrafiltration Process Design and Implementation, Chapter 10, in: Shukla, A. A., Etzel, M. R., and Gadam, S. (eds.), Process Scale Bioseparations for the Biopharmaceutical Industry, CRC Press, pp. $297-$ 332.

Oenning-Junior, A. and Pawlowsky, U., 2007, Evaluation of Advanced Technologies for Water Reuse in Mechanical Industry, Engenharia Sanitaria e Ambiental, Vol. 12, No. 3, pp. 305-316. [in Portuguese]

Peters, M. S. and Timmerhaus, K. D., 1991, Plant Design and Economics for Chemical Engineers, 4 ed., McGraw-Hill.

The Brazilian Ministry of the Environment (MMA), 2005, Regulation CONAMA 357, Article 34, MMA. [in Portuguese]

The National Water Agency (ANA), 1997, Law 9433: National Policy of Water Resources, Official Gazette, Brasilia, Section 1, p. 470, 9 January 1997. [in Portuguese]

The Sao Paulo State Government (CETESB), 1976, Decree 8468, Article 18, CETESB. [in Portuguese]
The World Health Organization (WHO), 1973, Reuse of Effluents: Methods of Wastewater Treatment and Health Safeguards, Technical Report Series, No. 517, WHO.

U. S. Environmental Protection Agency, 2004, Guidelines for Water Reuse, Report EPA/625/R04/108, U. S. Agency for International Development.

Vandevivere, P. C., Bianchi, R., and Verstraete, W., 1998, Treatment and Reuse of Wastewater from the Textile Wet-processing Industry: Review of Emerging Technologies, Journal of Chemical Technology and Biotechnology, Vol. 72, No. 4, pp. 289-302.

Westerhoff, G. P., 1984, An Update of Research Needs for Water Reuse, in: Water Reuse Symposium, 3, San Diego, CA, pp. 1731-1742.

Received: June 09, 2009

Revised: July 09, 2009

Accepted: August 09, 2009 